\title{
The Ownership of Religious Texts by Academic Libraries
}

\author{
Matthew Harris and Gregory A. Crawford
}

\begin{abstract}
This study examined the ownership of religious texts within academic libraries that were members of the Associated College Libraries of Central Pennsylvania (ACLCP). Texts from the Christian, Jewish, Islamic, Buddhist, Hindu, Morman, Ba'hai, Christian Scientist, Scientology, and Satanic faiths were included. The ACLCP Union Catalog was searched to find ownership of the specific texts in both English and their original languages. The results showed that most of the texts in English were indeed owned by the libraries included in the study, whereas the texts in their original languages were generally not owned. Due to the growing religious diversity of the students, faculty, staff, and community users of these libraries, ownership of religious texts has become more important in order to serve these individuals more fully.
\end{abstract}

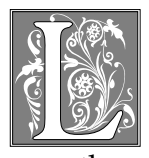

ibraries have as their primary mission the provision of information to their patrons and users. Although this sounds easy, there are some roadblocks. The most obvious roadblock is money; without it nothing can be bought. Beyond this monetary limitation, however, there are other factors that lead to a lack of resources. In collection development, a library tries to provide the patron with the best, most recent, and most accurate reference materials. But what happens when the source the patron wants has not changed in the past two thousand years but is available in many different versions? Take, for instance, The Holy Bible, a work fitting the aforementioned description. Many different versions are available in numerous languages, including the King James Version and the Revised Standard Version, which make it difficult to decide which version to collect. This would be a simple problem except that not everyone uses The Holy Bible as his or her main religious reference. Even certain sects of Christianity prefer different versions.

As of late, there has been a growing awareness of religious diversity. People would not be surprised if you were to discuss aspects of Buddhism or the basic tenants of Islamic faith. The world has become a global village with many different views on religion. An integration and acceptance on this scale is a great step toward true diversity, and knowledge provided by the library in the form of resources is a needed building block.

Creating a balanced collection in religion can be a daunting challenge. For most libraries, the overall goal of their collection development is to provide a wellrounded and balanced view of religion. Although this sounds easy, it should be

Matthew Harris is Adjunct Faculty at Harrisburg Area Community College; e-mail: subversion@submail.net. Gregory A. Crawford is Head of Public Services in the Library at Penn State Harrisburg; e-mail: gac2@psu.edu. 
remembered that religion has caused wars and is still causing conflict around the world simply because of different spiritual viewpoints. Some basic ideas that should be discussed in religion collection building are which religions are going to be represented, how not to focus on a single religion in favor of others, what is going to be used the most, and what are the seminal

\section{Creating a balanced collection in religion can be a daunting challenge.}

works in minority religions that should be owned. In an article by Susan Avallone, a survey was provided to public libraries dealing with many of the collection development questions involving religious materials. In response to one question, a librarian commented, "We don't have a need to include all religions ... we don't exclude any either." ${ }^{1}$ This general statement seems to be the mantra every librarian says right before he or she decides whether to buy a work such as The Satanic Bible by Anton LaVey. Inevitably, someone will feel slighted by any choice a librarian makes when deciding which religious texts to buy. What, then, should be the determining factors in religious collection development?

The intention of this study was to find out what religious texts were being collected in academic libraries, what determines a balanced collection, and which minor or obscure religions were being included in collections. The first step was to evaluate local academic library holdings to see whether the major religious texts were represented. Beyond this, the authors also wanted to explore which versions were collected of specific texts and also what obscure references were collected; by this, the authors included the texts of several fringe and minority religions in the United States. By comparison, current religious statistics were used as a way to gauge church population as a reason for overabundance or lack of some of the texts. More difficult to correlate would be actual interest shown for each religion in the libraries because statistics of this sort do not exist.
After the events of September 11, this research took on new meaning. As America faced its greatest modern tragedy, people were seeking answers. They turned to their local libraries as a resource for understanding a religion that has been misunderstood or overlooked by many Americans before it was thrust into the spotlight. The authors of this study hope that their research can provide a starting block for a reevaluation of religious collections. Knowledge remains the most important way to understand and increase tolerance.

\section{Literature Review}

Upon searching for literature that would pertain to this subject, there was little that directly reflected the proposed research. Most of the literature dealing with religion and libraries did not directly discuss collection development of primary religious texts. In fact, almost every article was aimed toward Christianity and not other world religions. For example, $A$ Basic Booklist for Church Libraries by Bernard E Deitrick was simply a list of recommendations for inclusion in church libraries. $^{2}$ Besides a more detailed explanation of particular books, this was a representative case of what most of the literature contained. James Michael Lee's article, "The Library and Religious Education," was a more esoteric look at what literature should be used to teach religion at parish and Catholic schools and what reference materials those schools' libraries should contain. ${ }^{3}$

One theme that recurs in the literature is that of handling donations of books on religious topics. Although this does have impact on the collection of religious materials, many of the articles deal with religious works that were not part of the core religious texts used in this study. An example would be a book such as The Bible Speaks to You by Robert McAfee Brown instead of The Holy Bible. Chris Kertesz, in "The Unwanted Gift: When Saying 'No Thanks' Isn't Enough," provided insight into why some books are rejected or accepted. ${ }^{4}$ Kertesz pointed out that contro- 
versy such as evolution versus creationism usually led to acceptance or denial for inclusion. It is noted that library policy usually sets the groundwork for avoiding such controversy. Again, this article discussed only literature that is related to religion, not the texts themselves. There was no mention of policies that set limits on what core religious texts should be accepted or rejected.

In "Receptivity to Religion" by Avallone, a mini-survey was sent to thirty public libraries across the nation. This survey posed questions such as, "Do libraries regularly buy popular inspirational and religious books for their collections?" and "Do libraries attempt to collect materials to 'balance' their book collections on such issues as the scientific theory of evolution against the fundamentalist theory of creation, or viewpoints favoring freedom of choice for abortion with those called 'pro-life'?"5 This article provided real-life answers to questions posed by the previous articles. It also showed the attitudes toward religious works by selected public libraries. Although interesting, here again no distinction was made between core religious texts and companion works. It was taken for granted that libraries would own core works. Assumptions such as this tend to be Christian-centric and overlook other non-Christian core works.

An article by David Gouker, "God Is Alive and Well At the Reference Desk," may help us understand the reason for searching out religious core works other than The Holy Bible and possibly why it is important to even discuss different versions of those core works. Gouker commented:

After decades of seemingly light interest in religious matters, many American library users are once again turning to God, and searching for religious information. In seeking answers, people have approached a variety of sources, including mainstream Christian churches, Judaism, non-Western religious traditions, fringe groups or cults, and conservative or fundamentalist Christian churches. ${ }^{6}$
This statement supports the reason the authors of this study chose to look at other religious works in addition to The Holy Bible. Perhaps it is just this simple swing of curiosity that has led to a renewed interest in all religious works. Besides chronicling one reference librarian's encounter with the new religious questioning, the article gave advice for dealing with this phenomenon. Goucker stated that "A sensitive, open, nonjudgmental attitude is essential for librarians dealing with people who hold strong religious beliefs." ${ }^{\prime 7}$ He continued, "it is important that we do not let personal prejudices or possibly even religious misconceptions interfere with our ability to take seriously and meet the information needs of people holding those views." 8

This resonates with the topic of the current research. It is important to look at everything with an open mind. Even though there is currently a lack of supporting literature on this topic, it is plausible to predict that as more reference librarians are confronted with questions about different religions, more literature will be written. And as a more diverse population seeks religious materials representative of their own spiritual path, it will be important to include literature in our libraries that reflect this multiculturalism. Even current political climates provide more than enough motivation for libraries to reconsider their religious collection.

\section{Methodology}

For many religions, determining their sacred or holy texts is immediately apparent. For example, Christians maintain that The Holy Bible is the "word of God," whereas Muslims make their claim for The Holy Koran. Other religions, especially those originating in India, have many religious texts. For this research, the authors used sources such as The Encyclopedia of Religion, Harper's Dictionary of Hinduism, Guide to Buddhist Religion, and others to determine which works to use as the basis of this research..$^{9-11}$ Figure 1 provides the final listing of religious texts included in the study. 
To those unfamiliar with some of the works, a brief explanation of each is in order. The Holy Bible of the Christian churches has many various versions. Four of the more widely known versions were chosen for this study. The King James Version was the main English translation until the midtwentieth century. The Revised Standard Version is an American revision based on the Authorized Version. This version eliminates some archaic phraseology but attempts to keep close to the words of the original text. The Jerusalem Bible is an English version of a French Catholic translation that uses "Yahweh" instead of "Lord." Finally, the New English Version is a translation done in the early 1980s. To more clearly deviate between works, only whole primary works were included in this study. Therefore, works containing only part of the primary religious texts, just the New Testament, for example, were not included. For the Hebrew faith, the authors chose the Tanakh because it contains the whole of the Hebrew scriptures that encompass the Torah, Nevi'im, and Ketuvim. The Holy Koran, or Quran, is the main Muslim religious text believed to be the word of Allah revealed to Muhammad. The Bhagavad-gita and the Veda are among the primary Hindu works, whereas the Tripitaka Sutra is the general work for Buddhism. The authors also looked to other religions for primary works that may not be included in the main religions but nonetheless are important. The Book of Mormon was revealed to Joseph Smith by the angel Moroni and has been the basis for Mormonism ever since. Dianetics, written by L. Ron Hubbard, is the basis for the religious philosophy of Scientology, and Science and Health with Key to the Scriptures, by Mary Baker Eddy, is the basis for the healing aspect of Christian Science. The Kitab-I-aqdas is the primary work for the Baha'i faith; and The Satanic Bible, by Anton LaVey, is used as a religious text by those who practice Satanism. On a side note, Satanism according to LaVey, is not the belief in Satan but, rather, the belief in indulging in the pleasures of the world to their fullest extent.

\begin{tabular}{|l|}
\multicolumn{1}{c|}{ FIGURE 1 } \\
Religious Texts Used in This Study \\
\hline \hline Bible: King James \\
Bible: Revised Standard \\
Bible: Jerusalem \\
Bible: New English \\
Koran or Qur-an \\
Bhagavad-gita \\
Veda \\
Tanakh \\
Bhagavad-gita: Sanskrit \\
Koran: Arabic \\
Veda: Sanskrit \\
Tanakh: Hebrew \\
Tripitaka Sutra \\
Tripitaka Sutra: Sanskrit \\
Tripitaka Sutra: Chinese \\
Dianetics \\
Book of Mormon \\
Satanic Bible \\
Science and Health with Key to the \\
Scriptures \\
Kitab-i-aqdas \\
\end{tabular}

Another aspect of this research was the provision of sacred texts in their original languages for those individuals who were affiliated with that religious tradition. However, the authors realize that many followers of a religion may not be able to read the sacred texts in the original language (e.g., Arabic for the Holy Koran), but only in their native tongue (e.g., Urdu). For this research, seeking out all possible translations proved to be daunting. Thus, in addition to searching for holdings in English, the authors also wished to determine holdings in the language in which the works originally appeared. For example, in addition to the Jewish version of the Old Testament, the Tanakh, in English, the authors also searched for it in Hebrew. For the Holy Koran, the authors looked for Arabic versions. For the various Hindu and Buddhist texts, the authors searched for Sanskrit and/or Chinese versions.

To determine ownership of these religious texts by a selected group of academic libraries within central Pennsylvania, the Union Catalog of libraries that were mem- 


\begin{tabular}{|l|}
\multicolumn{1}{c|}{ FIGURE 2} \\
Academic and Research \\
Libraries Represented in the \\
ACLCP Union Catalog \\
\hline \hline Albright College \\
Alvernia College \\
Bucknell University \\
Dickinson College \\
Dickinson School of Law \\
Elizabethtown College \\
Franklin and Marshall \\
Gettysburg College \\
HACC \\
Juniata College \\
Kutztown University \\
Lebanon Valley College \\
Lycoming College \\
Messiah College \\
Millersville University \\
Penn College of Tech \\
Penn State Harrisburg \\
Shippensburg University \\
Susquehanna University \\
York College \\
\hline
\end{tabular}

bers of the Associated College Libraries of Central Pennsylvania (ACLCP) was searched for each individual title. The ACLCP Union Catalog represents the holdings of twenty academic and research libraries (figure 2). Of these, thirteen are private colleges or universities and seven are public institutions, including the State Library of Pennsylvania. At the time of the study, the smallest collection numbered approximately 86,000 volumes (Alvernia College) and the largest numbered 987,000 (State Library of Pennsylvania). The average number of volumes held by these libraries was approximately 250,000.

Upon searching the Union Catalog, the total number of libraries owning a copy of each work was recorded, as was the language (English and/or other original language) of the work. Table 1 shows the findings of the study.

\section{Results}

The results were somewhat unexpected. Of the four versions of The Holy Bible - King
James, Revised Standard, Jerusalem, and New English-every library, except two, owned every version. The Dickinson School of Law failed to own any of the specified versions, whereas Penn College of Technology owned only the King James and Jerusalem versions. Every library owned the Holy Koran, whereas the Bhagavad-Gita was missing only from the Dickinson School of Law. Ownership numbers fell from there, with only 55 percent of the libraries owning a version of the Veda, 50 percent owning the Tripitaka Sutra, and only 25 percent owning the Tanakh. Part of the reason for some of the lower ownership numbers is that this study only looked at complete collectionsfor example, looking at The Holy Bible and not the New Testament or looking at the Tanakh and not the Torah holdings.

The authors also researched deeper to discover whether any libraries owned original-language versions of each of the texts. The Holy Koran in Arabic had the most ownership, with nine libraries including it in their holdings. The Sanskrit version of the Bhagavad-Gita was owned by three libraries, and the Sanskrit version of the Vedas was owned by only one library. The Tanakh in Hebrew was owned by one library. Finally, three libraries owned both the Sanskrit and Chinese versions of the Tripitaka Sutra.

This study also included other minority, if not fringe, religions that have a main text on which they base their teachings. The two most-owned works were The Book of Mormon and Science and Health with Key to the Scriptures, which is the primary text for Christian Science. Each work was owned by eighteen of the twenty libraries. The next largest holding was Dianetics, the basis for Scientology, which was owned by fourteen libraries. Eight libraries owned the Kitab-i-aqdas by Baha'U'llah of the Bahai faith, whereas only three libraries owned The Satanic Bible.

Moreover, various religious population studies were researched in an attempt to justify the reasoning behind the ownership statistics. Table 2 shows church populations in the United States from 1950 to 2000 


\begin{tabular}{|c|c|c|c|c|c|c|c|c|}
\hline \multicolumn{9}{|c|}{$\begin{array}{c}\text { TABLE } 1 \\
\text { Total Number of Libraries Owning Religious Texts } \\
\end{array}$} \\
\hline & $\begin{array}{l}\text { Bible: } \\
\text { King James }\end{array}$ & $\begin{array}{c}\text { Bible: } \\
\text { Revised Standard }\end{array}$ & $\begin{array}{c}\text { Bible: } \\
\text { Jerusalem }\end{array}$ & $\begin{array}{c}\text { Bible: } \\
\text { New English }\end{array}$ & $\begin{array}{c}\text { Koran } \\
\text { or Qur-an }\end{array}$ & $\begin{array}{l}\text { Bhagavad- } \\
\text { gita }\end{array}$ & Veda & Tanakh \\
\hline Albright College & 1 & 1 & 1 & 1 & 1 & 1 & 0 & 0 \\
\hline Alvernia College & 1 & 1 & 1 & 1 & 1 & 1 & 0 & 0 \\
\hline Bucknell University & 1 & 1 & 1 & 1 & 1 & 1 & 1 & 1 \\
\hline Dickinson College & 1 & 1 & 1 & 1 & 1 & 1 & 0 & 0 \\
\hline Dickinson School of Law & 0 & 0 & 0 & 0 & 1 & 0 & 0 & 0 \\
\hline Elizabethtown College & 1 & 1 & 1 & 1 & 1 & 1 & 1 & 0 \\
\hline Franklin and Marshall & 1 & 1 & 1 & 1 & 1 & 1 & 1 & 1 \\
\hline Gettysburg College & 1 & 1 & 1 & 1 & 1 & 1 & 1 & 1 \\
\hline $\mathrm{HACC}$ & 1 & 1 & 1 & 1 & 1 & 1 & 1 & 0 \\
\hline Juniata College & 1 & 1 & 1 & 1 & 1 & 1 & 0 & 0 \\
\hline Kutztown University & 1 & 1 & 1 & 1 & 1 & 1 & 1 & 0 \\
\hline Lebanon Valley College & 1 & 1 & 1 & 1 & 1 & 1 & 0 & 0 \\
\hline Lycoming College & 1 & 1 & 1 & 1 & 1 & 1 & 0 & 0 \\
\hline Messiah College & 1 & 1 & 1 & 1 & 1 & 1 & 0 & 0 \\
\hline Millersville University & 1 & 1 & 1 & 1 & 1 & 1 & 1 & 1 \\
\hline Penn College of Tech & 1 & 0 & 1 & 0 & 1 & 1 & 0 & 0 \\
\hline Penn State Harrisburg & 1 & 1 & 1 & 1 & 1 & 1 & 1 & 0 \\
\hline Shippensburg University & 1 & 1 & 1 & 1 & 1 & 1 & 1 & 0 \\
\hline Susquehanna University & 1 & 1 & 1 & 1 & 1 & 1 & 1 & 1 \\
\hline York College & 1 & 1 & 1 & 1 & 1 & 1 & 1 & 0 \\
\hline
\end{tabular}

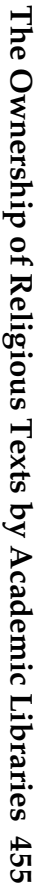




\begin{tabular}{|c|c|c|c|c|c|c|c|}
\hline \multicolumn{8}{|c|}{$\begin{array}{c}\text { TABLE } 1 \text { (continued) } \\
\text { Total Number of Libraries Owning Religious Texts }\end{array}$} \\
\hline & $\begin{array}{l}\text { Bhagavad-gita: } \\
\text { Sanskrit }\end{array}$ & $\begin{array}{l}\text { Koran: } \\
\text { Arabic }\end{array}$ & $\begin{array}{l}\text { Veda: } \\
\text { Sanskrit }\end{array}$ & $\begin{array}{l}\text { Tanakh: } \\
\text { Hebrew }\end{array}$ & $\begin{array}{l}\text { Tripitaka } \\
\text { Sutra }\end{array}$ & $\begin{array}{c}\text { Tripitaka } \\
\text { Sutra: Sanskrit }\end{array}$ & $\begin{array}{c}\text { Tripitaka } \\
\text { Sutra: Chinese }\end{array}$ \\
\hline Albright College & 0 & 0 & 0 & 0 & 0 & 0 & 0 \\
\hline Alvernia College & 0 & 0 & 0 & 0 & 0 & 0 & 0 \\
\hline Bucknell University & 0 & 1 & 0 & 0 & 1 & 1 & 1 \\
\hline Dickinson College & 0 & 0 & 0 & 0 & 0 & 0 & 0 \\
\hline Dickinson School of Law & 0 & 1 & 0 & 0 & 0 & 0 & 0 \\
\hline Elizabethtown College & 0 & 0 & 0 & 0 & 0 & 0 & 0 \\
\hline Franklin and Marshall & 1 & 1 & 1 & 0 & 1 & 1 & 1 \\
\hline Gettysburg College & 0 & 1 & 0 & 0 & 1 & 0 & 0 \\
\hline HACC & 0 & 1 & 0 & 0 & 1 & 0 & 0 \\
\hline Juniata College & 0 & 0 & 0 & 0 & 0 & 0 & 0 \\
\hline Kutztown University & 0 & 0 & 0 & 0 & 1 & 0 & 0 \\
\hline Lebanon Valley College & 0 & 0 & 0 & 0 & 0 & 0 & 0 \\
\hline Lycoming College & 0 & 0 & 0 & 0 & 0 & 0 & 0 \\
\hline Messiah College & 0 & 0 & 0 & 0 & 0 & 0 & 0 \\
\hline Millersville University & 1 & 1 & 0 & 0 & 1 & 0 & 0 \\
\hline Penn College of Tech & 0 & 0 & 0 & 0 & 0 & 0 & 0 \\
\hline Penn State Harrisburg & 0 & 1 & 0 & 0 & 1 & 0 & 0 \\
\hline Shippensburg University & 1 & 0 & 0 & 0 & 1 & 0 & 0 \\
\hline Susquehanna University & 0 & 1 & 0 & 1 & 1 & 0 & 0 \\
\hline York College & 0 & 1 & 0 & 0 & 1 & 1 & 1 \\
\hline
\end{tabular}


with major faiths represented, although some of the faiths have only recently been reported. As the table shows, the Roman Catholic Church has seen a 145 percent increase in church population since 1950, whereas Buddhism has seen a 401 percent increase since only 1980. Such trends show that minority religions are growing at a more rapid rate than established Christian denominations. Even though the minority religions have not reached the Roman Catholic Church's lofty population numbers, an increase could explain why some religious texts are being included in more libraries.

Table 2 shows that type of trend. Even though the percentage for people reporting other religious faiths and no religious

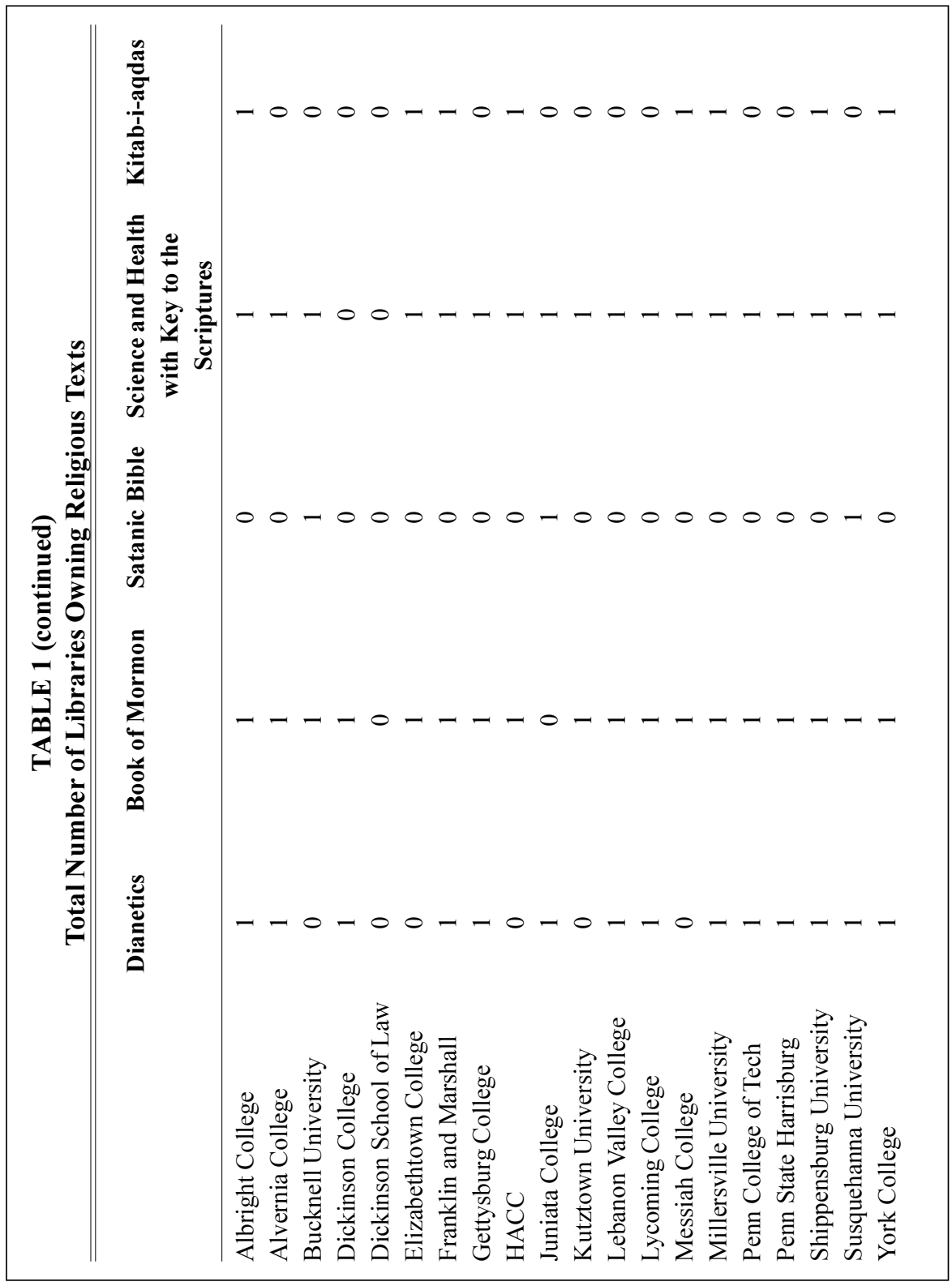


TABLE 2

Church Populations in the U.S., 1950-2000

\begin{tabular}{lrrrrrr}
\hline \hline (based on 1,000) & $\mathbf{1 9 5 0}$ & $\mathbf{1 9 6 0}$ & $\mathbf{1 9 7 0}$ & $\mathbf{1 9 8 0}$ & $\mathbf{1 9 9 0}$ & $\mathbf{2 0 0 0}$ \\
\hline Buddhist & $\mathrm{N} / \mathrm{L}$ & $\mathrm{N} / \mathrm{L}$ & $\mathrm{N} / \mathrm{L}$ & 60 & 100 & 401 \\
Hindu & $\mathrm{N} / \mathrm{L}$ & $\mathrm{N} / \mathrm{L}$ & $\mathrm{N} / \mathrm{L}$ & $\mathrm{N} / \mathrm{L}$ & $\mathrm{N} / \mathrm{L}$ & 227 \\
Jehovah's Witness & $\mathrm{N} / \mathrm{L}$ & 227 & 334 & 519 & 773 & 1,040 \\
Jewish & 4,641 & 5,500 & 5,780 & 5,781 & 5,944 & 6,041 \\
Muslim / Islamic & $\mathrm{N} / \mathrm{L}$ & $\mathrm{N} / \mathrm{L}$ & $\mathrm{N} / \mathrm{L}$ & $\mathrm{N} / \mathrm{L}$ & $\mathrm{N} / \mathrm{L}$ & 527 \\
Roman Catholic & 25,286 & 39,510 & 47,873 & 4,602 & 53,497 & 62,018 \\
Church of Jesus & & & & & & \\
$\quad$ Christ of Latter & & & & & & \\
Day Saints & 1,815 & 1,395 & 2,180 & 2,952 & 4,000 & 4,923 \\
& & & & & &
\end{tabular}

faiths is small, it has increased. This could also explain the possible inclusion of works such as Dianetics in library collections.

\section{Discussion/Implications}

This research provided fewer surprises than the authors had envisioned. What the authors thought would be a lack of diversity ended up being acceptable diversity. Libraries had many of the texts the authors were searching and even included other uncommon works such as Dianetics. This bodes well for many libraries, as the religious makeup of the United States is becoming more diverse. Again, the question remains, Are these libraries attempting to equally represent each religion, or are they in the mind-set that they only own works that have had in- terest shown in them? From this study, it does seem that equality and nonbiased decision making has given these libraries a balance of religious works.

After the tragedy of September 11, this research took on new meaning. What had been viewed simply as a study of ownership became an open door for discussion. Knowledge is the key to understanding and, therefore, people want to understand the rhetoric being passed around about the Taliban and its religious basis and about Islam. From this study, what was a surprise of diversity translates to the ability to provide the information these people are seeking. If anything comes from these inquiries, it will be due to the libraries being able to provide the vital information.

\section{Notes}

1. Susan Avallone, "Receptivity to Religion," Library Journal 109 (Oct. 15, 1994): 1892.

2. Bernard E. Deitrick, A Basic Book List for Church Libraries (1988). ERIC ED 314066.

3. James Michael Lee, "The Library and Religious Education," Catholic Library World 53 (MayJune 1982): 440-43.

4. Chris Kertesz, “The Unwanted Gift: When Saying 'No Thanks' Isn't Enough," American Libraries 32 (Mar. 2001): 34-36.

5. Avallone, "Receptivity to Religion," 1891.

6. David Gouker, "God Is Alive and Well at the Reference Desk," American Libraries 18 (May 1987): 342

7. Ibid., 342.

8. Ibid.

9. Mircea Eliade, ed., The Encyclopedia of Religion (New York: MacMillan, 1987).

10. Margaret and James Stutley, Harper's Dictionary of Hinduism (New York: Harper and Row, 1977).

11. Frank E. Reynolds, Guide to Buddhist Religion (Boston: G. K. Hall, 1981). 